Człowiek chory i umierający. Możliwości wsparcia i formy pomocy, red. J. Stala, Kraków 2014, Wydawnictwo Naukowe UPJPII, s. 167-180. http://dx.doi.org/10.15633/9788374384117.12

Monika Kaczor*

Uniwersytet Zielonogórski

\title{
CINIS ET MANES ET FABULA FIES SPOSOBY NOMINACJI ŚMIERCI W CZASOPISMACH SPOLECZNO-POLITYCZNYCH I SPOŁECZNO-KULTURALNYCH
}

\author{
(NA PRZYKŁADZIE „GAZETY WYBORCZEJ” \\ I „TYGODNIKA POWSZECHNEGO”)
}

W dyskursie prasowym o pewnych problemach zwykło mówić się w sposób charakterystyczny dla ogółu, zwyczajny lub bardziej wyrazisty i znaczący w kontekście określonych wydarzeń, spraw, okoliczności ${ }^{1}$. Wynikać to może z tego, że poważne zagadnienia i trudne do rozstrzygnięcia kwestie, nie dające się jednoznacznie wyjaśnić, wymagają odpowiedniego i specyficznego ujęcia za pomocą słowa. Ono to jest parametrem i miernikiem oceny tego, jak się myśli i mówi o tym, co nie jest łatwe ze względów socjologiczno-kulturowych. Z tym wiąże się także właściwe zastosowanie form językowych ze względu na społeczne i kulturowe uwarunkowania ich wyboru. $Z$ punktu widzenia pragmatyki przekazu ma to uzasadnienie w zagadnieniach związanych z kulturą słowa, etyką i estetyką języka, tabu językowym i aksjologizacją ${ }^{2}$.

\footnotetext{
* MONIKA KACZOR - adiunkt w Zakładzie Komunikacji Językowej Uniwersytetu Zielonogórskiego; zajmuje się kulturą języka polskiego, komunikacją językową w przekazach medialnych, etyką i estetyką słowa, ze szczególnym uwzględnieniem słownictwa etyczno-społecznego we współczesnym komunikowaniu i aspektach jego słownikowego opisu.

1 I. Borkowski, Śmierć i jej wartości w mediatyzowanym świecie, w: Antynomie wartości (problematyka aksjologiczna w językoznawstwie), red. A. Oskiera, Łódź 2007, s. 303-313.

2 Por. M. Kaczor, Tabu a estetyka językowa, „Język Polski” (2003) z. 1, s. 46-49.
} 
Jako że problemem, który w przekazach prasowych bywa postrzegany w sferze sacrum, jest śmierć, celem artykułu jest więc pokazanie, jak mówimy o śmierci oraz o tym, co ze śmiercia jest związane. Jak śmierć objawia się w języku prasy? Nie bez znaczenia jest również to, w jaki sposób mówienie o sprawach „niewygodnych językowo" wynika z profilu czasopisma oraz kontekstu pragmatyczno-kulturowego.

Problem zawarty w tytule artykułu wydaje się ważny z tego względu, że sposób nominalizacji poważnych, a tym samym wieloaspektowych i różnorodnych zjawisk, do których przynależy śmierć, wyznaczają środki językowe, pozwalające z jednej strony - zachować kulturalne wymogi obyczajowe w zakresie mówienia lub niemówienia wprost o sprawach objętych tabu językowym ${ }^{3}, \mathrm{z}$ drugiej strony - nazywać stosownie, sugestywnie, skutecznie, a także zgodnie ze stanem rzeczywistym to, co jest właściwe dla zjawiska śmierci.

W tym miejscu wypada poczynić pewne zastrzeżenie, wynikające z metodologicznego ujęcia omawianego problemu. W niniejszym opracowaniu śmierć będzie rozumiana jako pewny wycinek rzeczywistości ${ }^{4}$, funkcjonujących w językowym obrazie świata, będący obiektem licznych nominacji i interpretacji, w których widoczny jest silny związek między językiem a rzeczywistością pozajęzykową. Odwołania do ujęć filozoficznych będą wynikały z zabiegów językowych, utożsamiających śmierć z konkretnym, językowo nazwanym stanem, mającym związek z określonymi zasadami, ideami, leżącymi u podstaw konkretnego opisu.

Na potrzeby niniejszego opracowania wyekscerpowano z czasopism „Gazety Wyborczej” (GW) i „Tygodnika Powszechnego” (TP) ogółem 30 kontekstów, w których pojęcie śmierci pojawia się eksplicytnie i implicytnie. Szczególnemu oglądowi poddano numery pism, ukazujące się w związku z konkretnymi świętami (np. dzień Wszystkich Świętych, Dzień Zaduszny), wydarzeniami (np. rocznice śmierci, uroczystości wspomnieniowe wielkich katastrof, tragicznych wydarzeń), debatami politycznymi i medialnymi (np. aborcja medyczna, aborcja farmakologiczna, eutanazja czynna i bierna, klonowanie), nieprzewidzianymi sytuacjami, kończącymi się spekulacjami nad sensownością i celowością pewnych inicjatyw, w perspektywie których intensywniej i wyraźniej mówi się o śmierci. Ze względu na temat zawarty w tytule artykułu zanalizowano konteksty wypowiedzi, zawierające wymienione pojęcie, zamieszczone w tekstach polityczno-dziennikarskich: artykułach, komentarzach, opiniach, wywiadach, felietonach.

3 A. Jasik, Tabuizowanie tematu śmierci w kręgach środowiskowych Opolszczyzny, „Język a Kultura”. Tabu w języku i kulturze, t. 21, Wrocław 2009, s. 175-194.

4 Zob. J. Bartmiński, S. Niebrzegowska, Profile a podmiotowa interpretacja świata, w: Profilowanie w języku i w tekście, red. J. Bartmiński, R. Tokarski, Lublin 1998, s. 211-224. 
Wyekscerpowane ze wspomnianych czasopism wyrazy i wyrażenia można podzielić według kryterium formalnego, które pozwala mówić o nominacji syntetycznej i analitycznej, a także o kryterium sposobu wyrażania pojęcia śmierci (eksplicytnie, implicytnie) oraz kryterium nacechowania stylistycznego.

Rozważania na temat zawarty w tytule artykułu mają swoje uzasadnienie w jednym z najchętniej czytanych ogólnopolskich dzienników społeczno-politycznych w Polsce - „Gazecie Wyborczej”. Specyfiką mówienia o śmierci jest przyporządkowywanie jej określeń, które pełnią następujące funkcje:

- charakteryzujące lub jakościowe (nazywa przypadkową, niestałą cechę [właściwość] określonego pojęcia; wskazuje na cechę tego, co typowe, odpowiednie, stosowne w odniesieniu do tego pojęcia): absurdalna, bezbolesna, bezowocna, bezsensowna, biała, bliska, cudna, cudza, czarna, dobra, duchowa, fizyczna, godna, gwattowna, hańbiaca, jednostkowa, każda, lekka, lepsza, ludzka, młoda, młoda, nagła, naturalna, natychmiastowa, niechybna, niepotrzebna, niespodziewana, niesprawiedliwa, niezasłużona, nieuchronna, niewinna, normalna, okropna, okrutna, paskudna, pewna, piękna, polska, potrzebna, powolna, pozorna, prawdziwa, przedwczesna, przypadkowa, rychła, samotna, sadzona, smutna, straszna, szybka, świadoma, tajemnicza, tragiczna, wczesna, zadana, zagadkowa, zapomniana, $z \nmid a, z w y k ł a ;$

- wyodrębniające, klasyfikujące lub gatunkujące (wskazuje na konkretną, jedyną cechę): błogosławiona, bierna, bohaterska, całkowita, chwalebna, czynna, cywilna, duchowa, fizjologiczna, fizyczna, głodowa, górska, gwattowna, kliniczna, krzyżowa, męczeńska, naturalna, nienaturalna, polityczna, samobójcza, sercowa;

- odnoszące się do ilości: pierwsza, druga, pojedyncza, zbiorowa;

- wskazujące na posiadanie, przynależność; posesywność: ich, jego, nasza, swoja, twoja, wasza.

Na podstawie powyższego zastawienia określeń widać, że śmierć jest charakteryzowana z dużą swobodą. Wskazuje się głównie na przebieg, przyczyny, rodzaj, moment śmierci. Przedstawia się ją $\mathrm{w}$ aspekcie informacyjnym, jako obiektywne wydarzenie, powiadomienie, konkretny fakt, co może wynikać z założeń profilu czasopisma. Określenia, jakimi charakteryzowana jest śmierć, wskazują na różne sfery doświadczenia człowieka. Zatem śmierć jest stanem (faktem), opisywanym przez odniesienie do sfery biologicznej, która obejmuje określony wymiar egzystencjalnej, mentalnej, psychologicznej, sensorycznej i sensualnej sfery życia człowieka $\mathrm{z}$ uwzględnieniem także aspektu temporalnego. Omawiane pojęcie jest pokazywane w określonej perspektywie pragmatycznej, w której można 
dopatrzeć się również konotacyjnych cech filozoficznego ujęcia śmierci (por. krzyżowa, męczeńska).

Śmierć pojawia się kontekstach neutralnych i w tym ujęciu nie przypisuje się jej żadnego systemu, wedle którego byłaby ona wartością, aksjomatem, ideą („Stołeczna prokuratura wszczęła śledztwo w sprawie domniemanego przestępstwa nieumyślnego spowodowania śmierci uczestnika niedzielnego biegu w Warszawie", Stolica. Śledztwo w sprawie śmierci biegacza, GW, 07.10.2013).

W odpowiednim otoczeniu słownym synonimem śmierci są takie przykładowe określenia, jak:

- brak życia („Życie ludzkie, jako najważniejsze prawo człowieka, powinno być jego własnością, a wolność powinna mu dawać prawo do odebrania go sobie, jeżeli zaistnieją warunki, że człowieczeństwo zamienia się w wegetację istoty bez świadomości. Śmierć jest tu brakiem życia, którego i tak nie ma [...]", Prawo życia, prawo śmierci. Słowo eutanazja budzi w Polsce strach, GW, 25.01.2013);

- koniec życia organizmu (,Z etycznego punktu widzenia nie ma różnicy pomiędzy niepodłączeniem do aparatury, jeśli pacjent się temu sprzeciwia, a odłączeniem aparatury na jego życzenie. W obu przypadkach śmierć będzie koniec życia organizmu", Testament życia, to nie eutanazja, GW, 02.12.2008);

- niebyt („Umierać po ludzku to inicjatywa, której celem jest rozpropagowanie idei, że dobra śmierć ma sens i nie jest odejściem w niebyt", Umierać po ludzku - to nie eutanazja, GW, 15.05.2008);

- nieistnienie („W tradycji ludowej wierzono, że śmierć jest przeniesieniem duszy, jest nieistnieniem, Dziady, czyli zapomniane zwyczaje Wszystkich Swiętych i Zaduszek, GW, 31.10.2012);

- niezgoda na uporczywe leczenie („Dobra śmierć czyli niezgoda na uporczywe leczenie. Eutanazja, czyli pomoc w godnym odejściu. [...] W Polsce mamy problem $z$ dobrym odchodzeniem, lekarze często ratują chorych na siłę. Nie ma dyskusji, ani o śmierci, ani o rezygnacji z uporczywej i daremnej terapii. W Polsce, niestety, umiera się źle", Eutanazja to pomoc w godnym odejściu, czy śmierć na żądanie?, GW, 19.09.2012.);

- nieżycie („Działacze Prawa do Śmierci uznają, że śmierć przez eutanazję jest nieżyciem i jest zaprzeczeniem zabójstwa", Holandia. Eutanazja na telefon, „GW, 28.02.2012).

- przerwanie uporczywego uleczania („Janusz Palikot zapowiada, że w piątek RP przedstawi projekt ustawy o eutanazji. Jej główne założenie: centralny rejestr, w którym będzie można zgłosić chęć „przerwania uporczywego 
leczenia", Ruch Palikota: Zgłaszamy projekt ustawy o eutanazji. Bez słowa eutanazja, GW, 09.01.2013);

- odejście („Nagłaśniając ideę hospicjów, chcemy też przypomnieć, że umieranie to element życia, że należy o nim rozmawiać i nie można uciekać od tego tematu. Tu staram się, by śmierć była odejściem, godnym odejściem ...", Hospicjum to te $\dot{z} \dot{z} y c i e, \mathrm{GW}, 07.10 .2005^{\prime \prime}$;

- samobójstwo („Nieco częściej sprzeciw niż akceptację budzą inne sytuacje. Pomoc lekarza w samobójstwie pacjenta, które jest niczym innym, jak śmiercią, dopuszcza 43 proc. badanych, a potępia 48 proc., CBOS. Ponad połowa Polaków skłonna zaakceptować eutanazję, GW, 09.01.2013);

- śmierć mózgu („Aż 65 proc. badanych za dopuszczalne uważa zaprzestanie - za zgodą rodziny - podtrzymywania funkcji życiowych nieprzytomnego pacjenta $\mathrm{z}$ uszkodzonym mózgiem. Takie stan nie rokuje przywrócenia pacjenta do życia. [...] Następuje śmierć, z medycznego punktu widzenia nazywana śmiercią mózgu", CBOS. Ponad połowa Polaków skłonna zaakceptować eutanazję, GW, 09.01.2013);

- śmierć serca („Najczęściej negatywnie oceniana jest rezygnacja z podejmowania zabiegów reanimacyjnych w przypadku zatrzymania krążenia u ciężko i nieuleczalnie chorego pacjenta, u którego stwierdzono nieodwracalne zmiany $\mathrm{w}$ funkcjonowaniu wielu organów - krytycznie ocenia takie postępowanie 51 proc. badanych, a dopuszcza je 37 proc. [...] Prowadzi to do śmierci człowieka, nazywanej w języku medycznym śmiercią serca", CBOS. Ponad połowa Polaków skłonna zaakceptować eutanazje, GW, 09.01.2013);

- utrata życia („Śmierć, która nastąpiła w skutek eutanazji, jest utrata życia. Najczęściej negatywnie oceniana jest rezygnacja z podejmowania zabiegów reanimacyjnych w przypadku zatrzymania krążenia u ciężko i nieuleczalnie chorego pacjenta, u którego stwierdzono nieodwracalne zmiany w funkcjonowaniu wielu organów - krytycznie ocenia takie postępowanie 51 proc. badanych, a dopuszcza je 37 proc., CBOS. Ponad połowa Polaków skłonna zaakceptować eutanazje, GW, 09.01.2013);

- zatrzymanie funkcji życiowych (,Grupa liberalnych eurodeputowanych proponuje, by na forum unijnych instytucji zaczęła się debata o eutanazji, gdy śmierć byłaby równoznaczna z zatrzymaniem funkcji życiowych. Choć nie ma mowy o próbie uchwalenia unijnego prawa w tej kwestii, to już sama propozycja debaty wywołuje ostry sprzeciw", Porozmawiamy o eutanazji w Europarlamencie, GW, 10.07.2007);

- zatrzymanie życia („Premier podkreślił, że jest zdecydowanym zwolennikiem pracy nad kwestią zapłodnienia in vitro, sprawą testamentu życia [chodzi o wyrażenie zgody na pobranie organów po śmierci] oraz eutanazji, 
w wypadku zatrzymania życia, co jest równoznaczne ze śmiercią, ale bez emocji i wojny politycznej", Premier proponuje debatę o In vitro i eutanazji, GW, 07.03.2007;

- ustanie pracy organizmu („Podkreśla, że w debacie o eutanazji czy uporczywej terapii często zapomina się o godności człowieka. - Medycyna ma wyleczyć, a jeśli to niemożliwe, to przede wszystkim ulżyć w cierpieniu. A przedłużanie umierania zwiększa cierpienie, narusza godność człowieka. Chodzi zatem o eutanazję, w której śmierć jest rozumiana jak ustanie pracy organizmu”, Prośba o dobra śmierć, GW, 19.01.2013).

Semantycznie powyższe nazwy nawiązują do:

- stanu organizmu, polegającego na przerwanym ciągu procesów, w których człowiek reaguje na szereg bodźców i czynników;

- przestania (przestawania) funkcjonowania organizmu, zaniku określonych czynności, właściwych dla żywego organizmu;

- stanów zagrożenia życia, skutkujących jego utratą;

- nieodwracalnego pozbawienia człowieka biologicznych czynności w następstwie działania czynników zewnętrznych;

- gwałtownego oddziaływanie (działanie) na organizm, co powoduje zaprzestanie funkcjonowania określonych czynności przed ich naturalnym zatrzymaniem;

- straty życia (siły żywotnych) wskutek czegoś;

- celowego odebrania życia w skutek działania innych czynników (np. osób, substancji, urządzeń);

- zabiegów podjętych w celu nieprzywrócenia człowieka do życia;

- ostateczny koniec życia człowieka w znaczeniu biologicznym i w pewnych warunkach egzystencji;

- nieistnienia, nicości, braku, próżni;

- momentu, chwili, w której coś się kończy; ostatniej części jakiegoś okresu, stadium, fazy;

- kres, schyłek, zmierzch.

Znaczenie nazwy śmierć bywa weryfikowane przez umieszczenie w specyficznie skomponowanym kontekście słownym. Ta modyfikacja kontekstowa może zostać odebrana jako przekraczanie granicy tabu językowego (kulturowego). Wśród określeń, wprowadzających nacechowanie pejoratywne oraz kwalifikację pogardliwą w stosunku do pojęcia śmierci, a w konsekwencji także i dla zjawiska, znajdują się takie przykładowe sformułowania, jak: funeralna tandeta, tabloizacja śmierci (Funeralna tandeta, GW, 26.10.2011). Również fragmenty, w których pojawia się substantivum śmierci, wskazują na krytykującą rozbieżność między wyobrażeniem o śmierci, a jej „praktyczną” realizacją. Oto stosowny fragment, 
w którym śmierć jest hiperonimem dla połączeń wyrazowych dzień wszystkich wiernych zmarlych, dzień zaduszny, dzień zmarlych, święto bezimiennych świętych, 1 listopada: „Dzień zmarłych coraz bardziej przestaje być zależny od sfery metafizyki; przestaje mieć styczność z egzystencjalną problematyką granicy i skończoności. Dziś chodzi głównie o to, by coś kupić, zapalić i oddać naszych kochanych zmarłych w ręce wszechobecnego kiczu. Dzień zmarłych czy dzień zaduszny przez wiele setek lat były okazją do kontaktów z nieznanym", Funeralna tandeta, GW, 26.10.2011.

W zebranym materiale śmierć, jako wyraz o znaczeniu ogólnym, stanowi nazwę określonej grupy wyrazów i sformułowań wobec niego podrzędnych i bardziej szczegółowych znaczeniowo, będących jego hiponimami. W procesie dekodowania nazwy ujawniają się cechy konotacyjne, przypisywane śmierci. Oto kilka z nich: tamta strona życia (GW, Jan Turnau: słowo na Wszystkich Świętych, 31.10.2006); „czasoprzestrzeñ” zaświatów, brama śmierci, [...] czyli świat który Bóg dla nas przygotował, brama zaświatów, druga, jasna strona życia, mrokach szeolu czy Hadesu, nieustający uplyw czasu, ponura quasi-egzystencja, przyszłe życie, wieczne nabożeństwo, zaświaty (GW, Po drugiej, jasnej stronie, o1.11.20o8); kościotrup $w$ białej płachcie; zapalenia wirtualnego znicza (GW, Wszystkich Świętych: Tradycja i nowości na cmentarzach, 31.10.2009); czekać na niebo, pójść do góry (GW, 1 listopada to nie Święto Zmarlych, 27.10.2003); pytania o sens życia, pytania o to, co po śmierci (Święto bezimiennych świętych, GW, 03.11.2008).

Niemówienie wprost o śmierci realizuje się dzięki wykorzystywaniu wyrazów lub sformułowań zastępczych. Unikanie bezpośredniego przywoływania śmierci może wynikać ze względów kulturowych, obyczajowych, a w pewnym stopniu także z upowszechniania się kultury hedonistycznej, kultu życia i młodości. W celu złagodzenia lub osłabienia znaczeniowej doniosłości wspomnianego słowa stosuje się eufemistyczne określenia i sformułowania. Z jednej strony eliminują silne zabarwienie emocjonalne przekazu, $\mathrm{z}$ drugiej - poszerzają pole znaczeniowe analizowanego pojęcia.

Daje się także zauważyć pewną konwencję stylistyczną, polegającą na odpowiednim (celowym) doborze słownictwa i określonych przekształceniach semantycznych, por. kostucha kogośnawiedza, wybrać się do Abrahama na piwo (Chrześcijan zaglądanie do środka, GW, 21.02.2012).

Miana, a więc określenia i sformułowania odnoszące się do śmierci, stają się swoistymi etykietkami, niekiedy deprecjonującymi i redukującymi znaczenie śmierci, bo utrwalającymi te jej aspekty, które eliminują jej religijny aspekt. Są obarczone treściami, które odsyłają do niereligijnych (nietranscendentalnych?) aspektów życia człowieka, a więc do tego, co jest właściwe potocznemu myśleniu. Wykorzystywanie słownictwa $\mathrm{z}$ rejestru języka potocznego staje się dominantą 
stylistyczną i nabiera tym samym określonej wartości stylistycznej. Celowość takich zabiegów językowych podświetla laicyzację, która jest sposobem mówienia o śmierci jako jednym z elementów ludzkiego życia. Uwagę zwraca także potoczność i tendencja do żartobliwego formułowania treści, która odstrasza kiczowatością. Język tego rodzaju opisów utrwala zeświecczenie obyczajów oraz tendencje do pauperyzacji i trywializacji treści związanych z końcem ludzkiego życia.

Przytoczone przykłady określeń świadczą również o tym, że ubożeje język mówienia o sprawach ostatecznych człowieka. Wyrażona w nich treść ma formę uproszczoną, nie mającą czasami nic wspólnego z tego rodzaju przesłaniem. W warstwie aksjologicznej i semantycznej nie nawiązują do tego, co jest treścią końca życia człowieka.

Wśród zastosowanych sposobów nominacji zwraca uwagę kontrast, polegający na zderzeniu tego, co swoiste i dominujące dla religii („Jednak większość ludzi, którzy odwiedzają w tych dniach groby zmarłych, robi to w celu modlitwy, a przystrajanie grobów jest tylko zewnętrznym znakiem. To modlitwa jest tym, co zmarłym potrzebne jest najbardziej. Polacy, niestety, coraz bardziej się laicyzują, jednak praktycznie wszyscy wychowani w katolickiej tradycji, nawet jeśli nie są praktykujący, pamiętają o tym, aby nad grobem bliskich się pomodlić, przynajmniej uczynić znak krzyża, a nie tylko zaświecić znicz czy postawić kwiaty", Znicze, kwiaty i modlitwa - oto nasza tradycja, GW, 03.11.2012), obyczajowości („W tradycji ludowej wierzono, że przesilenie, np. jesienne, gdy zamiera przyroda, to czas, gdy dusze naszych zmarłych powracają do swoich domostw. Dlatego też w tym okresie, przypadającym na przełom października i listopada, kultywowano zwyczaj zwany Dziadami”, Dziady, czyli zapomniane zwyczaje Wszystkich Świętych i Zaduszek, GW, 31.10.2012), z laicyzacją („Portale internetowe prowadzą akcję wirtualnego zapalania zniczy na grobach bliskich dla tych, którzy nie mogą pojawić się na rodzinnych cmentarzach", Wszystkich Świętych: tradycja i nowoczesność na cmentarzach, GW, 30.10.2009). Stąd pojawiają się takie opozycje znaczeniowe, odnoszące się do śmierci, jak: świadomość tego, co nas przekracza; świadomość granicy; świadomość tajemnicy; świadomość nieskończoności, świadomość problemów winy i odpuszczenia grzechów; śmierć i trup; zwyczaje cmentarne; cmentarna tandeta; metafizyka i tajemnica śmierci; przemijalność; kruchości życia, Funeralna tandeta, GW, 26.10.2011. Sprzyja to wydobyciu skomplikowanych, odpowiadających dialektycznej złożoności aspektów śmierci w wymiarze świeckim i duchowym.

Językowe wyrażanie tego, co związane jest ze śmiercią oscyluje między sformułowaniami jawnie krytykującymi, przez ironiczne, aż po filozoficzne:

- „Cmentarna tandeta oddala nas od metafizyki i tajemnicy śmierci. Żywych oddala od refleksji o przemijalności i kruchości naszego istnienia tu, na 
ziemi. Myślę, że odstrasza również duchy naszych zmarłych. Ale może o to chodzi", Funeralna tandeta, GW, 26.10.2011;

- „Cmentarze zalewane są mnóstwem brzydkich przedmiotów symbolizujących raczej upadek naszej kultury niż pamięć o nieżyjących. Nie mówię nawet o ubolewania godnych artystycznych eksperymentach zwanych nagrobkami. [...] Nagrobki, trudno! Ale te sztuczne kwiaty i potworne znicze! Obecność tych pierwszych powoduje, że nie wiadomo, czy jest się na cmentarzu, czy na wiejskim odpuście”, Funeralna tandeta, GW, 26.10.2011.

- „Przypominamy sobie dzisiaj o tych, którzy między nami byli. Choć słowo «przypomnienie» nie jest może właściwe, bo tak naprawdę pamiętamy o nich zawsze", Wszystkich Świętych na białostockich cmentarzach, GW, 01.11.2005.

Wśród zastosowanych sposobów nominacji uwagę zwracają również te, które są formą powiązań i odniesień międzytekstowych, wobec których jest definiowane pojęcie śmierci. Te intertekstualne obszary wypowiedzi mają wyraźne rozpoznawalny charakter. Pozostając w kontekście rozważań z tekstem głównym (prasowym), są formą nawiązania kontynuacyjnego, rodzajem odwołania, polemiki, przez co wprowadzają pewnego rodzaju dialogowości i poszerzają zakres znaczeniowy pojęcia śmierci: „Nowy Testament zna jeszcze wiele innych metafor tego, co Bóg dla nas przygotował. Wspólny wyróżnik tych obrazów podaje św. Paweł. Treścią wykraczają one daleko poza nasze możliwości poznawcze, poza najśmielszą nawet wyobraźnię: «Ani oko nie widziało, ani ucho nie słyszało, ani serce człowieka nie zdołało pojąć, jak wielkie rzeczy przygotował Bóg tym, którzy Go miłują» (1 List do Koryntian 2, 9). Te słowa są jak studnia. Niosą też otrzeźwienie, gdybyśmy za bardzo chcieli zaufać naszym wyobrażeniom Boga i życia za bramą śmierci. Słowa współgrają z tradycją «teologii negatywnej», to jest mówiącej, kim Bóg nie jest, czym nie jest świat, który dla nas przygotował. «Uczona niewiedza» (Mikołaj z Kuzy) broni tajemnic bożych przed ich spłyceniem, chroni potęgę i blask Boga przed językiem, w którym «każde słowo zaczyna się i kończy» (św. Augustyn). Tajemnica życia wiecznego zbawionych "przekracza wszelkie możliwości naszego zrozumienia i wyobrażenia»" - przeczytamy w Katechizmie Kościoła Katolickiego (1024, 1027), GW, Po drugiej, jasnej stronie, 01.11.2008.

Zgoła inaczej przedstawia się rzecz w społeczno-kulturalnym piśmie - „Tygodniku Powszechnym”. Różnica polega przede wszystkim na odmiennej retoryce ${ }^{5}$, która buduje egzystencjalno-duchowy obraz kresu ludzkiego życia, gdzie „śmierć

5 T. Zgółka, Retoryka tabuizacji, „Język a Kultura”. Tabu w języku i kulturze, t. 21, red. A. Dąbrowska, Wrocław 2009, s. 23-29. 
ciała i mózgu nie są końcem świadomości, że ludzkie doświadczenie wykracza poza grób” („Tygodnik” na Wszystkich Świętych, TP, 04.11.2012).

W nominacji metaforycznej, która jest wyraźnym sposobem określania śmierci, eksponuje się obraz drogi, jej początku i końca, przejścia z jednego brzegu na drugi, będącej przygotowaniem wewnętrznym człowieka na moment finalizacji życia. Refleksyjno-intelektualny charakter nazywania śmierci pozostaje w zgodzie z chrześcijańskim myśleniem o niej:

- „Być może czeka nas coś po drugiej stronie, być może umiejętność przyjęcia kresu jest dowodem duchowego rozwoju. A przecież ludzkie istnienie jest skierowane przeciwko śmierci, także tej drugiej, niemal równie bolesnej, jaką jest zapomnienie", Furtka czarnego ogrodu, TP, 27.10.2009.

- „W śmierci osiąga swą pełnię to, co w ciągu całego życia dokonywało się za pośrednictwem sakramentów, zwłaszcza chrztu i Eucharystii. Znaki sakramentalne są zapowiedzią spotkania bez zasłony". Dlatego, przekonuje ks. Hryniewicz, modląc się o dobre i spokojne umieranie, prosimy w istocie Boga o pomnożenie w nas samych zdolności do miłowania”, „Tygodnik” na Wszystkich Świętych, TP, 04.11.2012.

- „[...] ze śmiercią kończy się wprawdzie definitywnie ziemska droga naszego pielgrzymowania [...]", Gdzież jest, o śmierci, twój oścień, TP, 12.04.2009.

Z perspektywą drogi wiąże się jej koniec, a więc moment, chwila, w której wędrówka się kończy. W tej alegorycznej interpretacji zawarte jest przesłanie śmierci jako ostatniej części okresu życia, jego zmierzchu, zakończenia, stąd relatywnie często pojawia się sformułowanie dobra śmierć. Konotuje ono pożądane cechy życia człowieka, wynikające ze szlachetnych i prawych wyborów, zgodnych z zasadami moralnymi: „Dobra śmierć. To połączenie słów może budzić sprzeciw, także wśród wielu chrześcijan. A przecież śmierć dobrze przygotowana, przyjęta jako konieczność, ale też jako wypełnienie i przejście - taka śmierć staje się końcowym znakiem prawdziwie chrześcijańskiego życia tu, na ziemi. To prawda, nie każdego na nią stać, ale też podjęte zawczasu przygotowania do jej świadomego i godnego przyjęcia nie są jakimś nadludzkim wysiłkiem. Wystarczy zacząć od namysłu. Im wcześniej uświadomimy sobie, że całe nasze życie, włącznie z dzieciństwem i młodością, zmierza do tej jednej i niepowtarzalnej chwili, tym dla nas lepiej", Dobra śmierć, TP, 03.04.2011.

Śmierć jako kryterium, miernik, miara, sprawdzian z jakości życia, po jego ukończeniu - to kolejne przenośne ujęcie końca drogi człowieka. Mówi o tym autor wywiadu w następujący sposób: „Pozwala mi to raczej rozumieć zbliżanie się śmierci jako ostatniego egzaminu z miłości”, Nie interesuje mnie śmierć, TP, 19.12.2009. 
Symbolicznym ujęciem śmierci jest brama. Jak pokazuje to poniższy kontekst, w interpretacji semantycznej wskazuje się na treści głęboko ukryte, ku którym winna się kierować myśl człowieka. Ukryty sens bramy pozwala utożsamiać ją z przejściem ze świata żywych do świata zmarłych, ze świata ziemskiego do świata sacrum. Daje się rozpoznać w niej także wyobrażenie o pewnym końcu i początku czegoś: „Nie interesuje mnie śmierć jako umieranie, ale jako brama otwierająca pełnię życia. [...] Do nieba można wejść tylko wtedy, gdy się kocha życie, a nie, gdy się je odrzuca", Nie interesuje mnie śmierć, TP, 19.12.2009.

Ze znaczeniem śmierci jako bramy wiąże się jej kolejny metaforyczny atrybut - przejście, rozumiane jako przeobrażenie, nadanie początku czemuś innemu, nowemu: „Popatrzmy bliżej w oczy tej naszej śmierci, temu naszemu na śmierć skazaniu. Czymże ona jest? Czujemy bardzo niewyraźnie, że jest jakimś nadciągającym ku nam nieustannym przepływaniem istnienia w nieistnienie. To przepływanie rozgrywa się na różnych płaszczyznach bytu", Naprawić ludzka śmierć, TP, 18.03.2008.

Zarówno brama jak i moment przejścia realizuje się w określonym czasie, który, jak na to wskazuje kolejny fragment, jest domeną śmierci: „Śmierć ujawnia się nam przede wszystkim poprzez płynący czas. Czas zabiera moment po momencie i nieustannie zapada w przeszłość. Nigdy nie wraca, wciąż płynie. Obecna chwila przemija i zabiera ze sobą jakąś część naszego serca, naszego bytu. Nigdy nie wróci. Moment zmarnowanego życia jest momentem zmarnowanego życia na wieki. Widzimy ponadto, że śmierć płynie poprzez naszą wolność. Kiedy w wolny sposób coś wybieramy, zawsze dzieje się tak, że wybierając jedno, porzucamy drugie. I nasza wolność jest takim nieustannym porzucaniem czegoś. Zawsze w życiu coś porzucać musimy. W tym nieustannym porzucaniu dany nam jest tragiczny przedsmak tego, że kiedyś będziemy musieli porzucić wszystko", Naprawić ludzką śmierć, TP, 18.03.2008.

Wśród określeń metaforycznych uwagę zwracają te o charakterze podniosłym: dokonać swoich dni, dokonać życia, dusza rozstała się z ciałem, godnie rozstać się $z \dot{z} y c i e m$, miejsce spokoju, oddać bogu ducha, pożegnać się ze światem, pójść na tamten świat, przechodzenie dusz, przejść do innego życia, przenieść się do wieczności, rozstać się z życiem, śmierć kogoś zabrała, śmierć pocięła komuś życie, w proch się obrócić, wybrać się na tamten świat, wydać ostatnie tchnienie, zakończyć życie, zamknąć oczy na zawsze, zasnąć, zasnąć snem wiecznym, zejść, zejść do grobu, zgasła pochodnia czyjegoś życia, złożyć swoje kości, życie i śmierć - początek i koniec, życie z kogoś uszło.

Metaforyczne sformułowania podkreślają, że śmierć należy do językowego i kulturowego tabu. Myślenie i mówienie o niej wzbudza lęk, jest trudne, niełatwe do zrozumienia, pełne niejasności i skomplikowane. Wydaje się, że posługiwanie 
się określeniami nie wprost nie budzi kontrowersji. Stąd w językowej konfrontacji ze śmiercią ze względów emocjonalnych pojawiają się określenia eufemistyczne i przenośne, które z jednej strony uwznioślają obraz śmierci, z drugiej - pozwalają oswoić się z nieuchronnością śmierci.

Warto zaznaczyć, że wyraźnym komponentem językowego wizerunku śmierci jest kreowanie wspólnoty z perspektywy człowieka wierzącego oraz określanie jej tożsamości:

„Ludzie, którzy zmarli w stanie łaski i są u Boga, tworzą idealną wspólnotę, będącą prototypem wspólnoty, która kiedyś, po zmartwychwstaniu ciał, stanie się także naszym udziałem. [...] Wspólnota świętych również komunikuje dobrem, bo widzi Boga, a to ją przemienia i nasyca boskim Dobrem. Stąd wspólnota świętych jest promieniującą dobrocią samego Boga. Między nieudaną wspólnotą ludzi na ziemi a udaną wspólnotą świętych istnieje więź, która umożliwia komunikatywność dobra", Radość, która nas czeka, TP, 1.111.2009.

Aksjologizacja śmierci dokonuje się także poprzez zestawienie wartości i antywartości: życie-wegetacja; substancjalność, nieutracalność-przypadkowość, przemijalność. Atrybuty śmierci wyłaniają się w wyniku przywoływania takich przykładowych leksemów wartościujących, jak: atrakcja, atrakcyjność, promieniować, radość, urok: „Jedyna rzecz absolutnie pewna to śmierć. A śmierć otwiera perspektywę ogromnie atrakcyjną. [...] Mówię o atrakcyjności Boga. Jego obecność promieniuje nieskończonym urokiem. W śmierci poddajemy się temu urokowi. Przechodzimy do pełni życia, wobec której życie po tej stronie jest właściwie wegetacją. Dlatego śmierć pociąga. Wzbudza radość. Radość, jaka nas czeka, ma charakter substancjalny, nieutracalny, w przeciwieństwie do radości ziemskiej, która zawsze jest przypadkowa i przemijająca", Radość, która nas czeka, TP, 1.11.2009.

Jako że po ludzku śmierć jest nie do zrozumienia i wyjaśnienia, próbuje się jej nadać określone charakterystyczne „parametry”. Tak więc kolejnym sposobem nominacji śmierci będzie nazywanie jej poprzez antynomię pojęć: bezkompromisowa i bezlitosna sprawiedliwość, bezradnośc, bezsens, dramat, dramat ludzkiego istnienia, finalne stadium człowieka i dziejów ludzkości, godzina rozliczenia, lęk, mroczna tajemnica, niepewność, nieszczęście, niezrozumienie, obrzydzenie, oczekiwanie, ostatnia godzina, ostatnia prosta swojego życia, ostatnia nierozwiązana zagadka świata, protest, przypadkowość, przypadkowy najeźdźca z zewnatrz, pustka, skończoność, strata, szaleństwo żalu, tęsknota, trwoga, życie wśród złudzeń, unieszczęśliwienie: bilans plusów i minusów, błogosławione owoce, ciała zmartwychwstanie, komunia, los wieczny, miecz sprawiedliwości, nadzieja, nieskończoność, pokój, prawdziwe szczęście, radość, Sąd Boży, spotkanie bez zastony, szczęcie wieczne, tęsknota za niebem, tęsknota za życiem wiecznym, trwałość, wieczna przystań człowieka, wieczna szczęśliwość, życie prawdziwe, żywot wieczny. W sprzeczności między 
wykluczającymi się pojęciami, z których każde wydaje się prawdopodobne, równie prawdziwe i uzasadnione, utrwala się wartościujące nazywanie śmierci. Wskazują one również na konsekwencje śmierci i na określony porządek wartości, w których główną zasadą jest: warto lepiej żyć. Kryją w sobie zachętę do dobrego życia, ale też i przestrogę przed życiem jakby śmierci nie było, i w konsekwencji refleksję, że śmierć kończy życie, ale też, że śmierć istnieje po to, by życie mogło trwać.

Z powyższych rozważań można wyprowadzić następujące wnioski.

Mówienie o śmierci w przekazach prasowych ujawnia inny (nowy??) typ religijności, a co za tym idzie, inny obraz kultury umierania niż to ma miejsce w kulturze ludowej ${ }^{6}$. Można zaryzykować stwierdzenie, że śmierć jest coraz mniej obecna w prasie. W jej miejsce stopniowo pojawia się mówienie o kulturze umierania.

W czasopismach zarówno tych o charakterze społeczno-politycznym, jak i tych społeczno-kulturalnych mówi się o pojęciu śmierci. W tych pierwszych dominuje kontekst potoczny i biologiczny, w drugich - egzystencjalny, moralno-etyczny, filozoficzny i duchowy. Budowanie językowego obrazu końca życia człowieka jest uwikłane w konteksty pragmatyczno-społeczno-kulturowe, realizowane w treściach (przesłaniach) artykułów. W przekazach prasowych jest kojarzona przed wszystkim ze sferą sacrum (religią), ale także pojawia się w kontekstach zsekularyzowanych.

Językowy wyraz śmierci jest uwarunkowany profilem czasopisma, stąd w przedstawionych pismach widoczne jest budowanie odmiennych jej wizerunków. Swoista inność w tym zakresie wynika ze struktury znaczeniowej nazw, ich konotacji i nacechowania pozytywnego lub negatywnego. W strukturze znaczeniowej nazw pojawiają się cechy konotacyjne oraz ich wartościująca ocena, co prowadzi do substancjalizacji śmierci. Opatrywanie śmierci różnymi określeniami (epitetami wartościującymi) wskazuje na domeny życia człowieka, z którymi jest kojarzona, a także zwraca uwagę na sposób jej postrzegania i odbierania przez człowieka, jako istoty doświadczającej śmierci.

Sposobowi mówienia o śmierci podporządkowana jest poetyka przekazu, a więc repertuar środków językowych, nacechowanych emocjonalnie, mających wpływ na aksjologiczne ujęcie problemu przemijania życia człowieka w znaczeniu, biologicznym, egzystencjalnym, moralno-etycznym, filozoficznym i duchowym. Uwagę zwraca kreowanie językowego wizerunku śmierci z perspektywy wartości i antywartości. Dlatego atrybutem jest wszystko to, co prowadzi do dobrej, godnej

${ }^{6}$ H. Biegeleisen, Śmierć w obrzędach, zwyczajach ludu polskiego, Warszawa 1930; M. Bonowska, Przemijanie. Śmierć, pogrzeb, życie pozagrobowe w wyobraźni mieszkańców Pomorza Zachodniego na przełomie XIX i XX wieku, Poznań 2004. 
śmierci, której przeciwieństwem jest ta niepotrzebna i przypadkowa, przez którą eksponuje się cechy niezgodne z chrześcijańskimi cnotami.

W przekazach prasowych śmierć jest obrazowana przez odwołania do metafor, przenośni, symboli, które dowodzą głównie biologiczno-egzystencjalnego oraz duchowego i moralno-etycznego wydźwięku nominacji.

W sposobach nominacji utrwala się albo kultura degradacji śmierci (umierania), przejawiająca się w głównie w obniżeniu jej moralnego sensu, albo jej nobilitacja, przywracająca właściwe myślenie o końcu ludzkiego życia.

\section{Proponowana literatura}

Bartmiński J., S. Niebrzegowska, Profile a podmiotowa interpretacja świata, w: Profilowanie w języku i w tekście, red. J. Bartmiński, R. Tokarski, Lublin 1998, s. 211-224.

Biegeleisen H., Śmierć w obrzędach, zwyczajach ludu polskiego, Warszawa 1930.

Bonowska M., Przemijanie. Śmierć, pogrzeb, życie pozagrobowe w wyobraźni mieszkańców Pomorza Zachodniego na przełomie XIX i XX wieku, Poznań 2004.

Borkowski I., Śmierć i jej wartości w mediatyzowanym świecie, w: Antynomie wartości (problematyka aksjologiczna w językoznawstwie), red. A. Oskiera, Łódź 2007, s. 303-313.

Burzyńska A. B., J. Kamieniecki, Wpływ przeszłości na jezzykowy obraz śmierć ludzi i zwierząt w polszczyźnie, „Etnolingwistyka” 10/11 (1997/1998), s. 81-92.

Engelking A., Istota i ewolucja eufemizmów (na przykładzie zastępczych określeń śmierci), „Przegląd Humanistyczny” (1984) nr 4, s. 115-129.

Jasik A., Tabuizowanie tematu śmierci w kręgach środowiskowych Opolszczyzny, „Język a Kultura”. Tabu w języku i kulturze, t. 21, red. A. Dąbrowska, Wrocław 2009, s. 175-194.

Kaczor M., Tabu a estetyka językowa, „Język Polski” (2003) z. 1, s. 46-49.

Krzyżanowska A., Ostatnia podróż - czyli polska i francuska metaforyka śmierci, „Etnolingwistyka" 10/11 (1997/1998), s. 93-109.

Marciniak R., Określenia śmierci i umierania w inskrypcjach nagrobkowych cmentarzy w Łowiczu i Załakowie Kościelnym, w: Tabu językowe i eufemizacja w dialektach słowiańskich, red. F. Czyżewski i A. Tyrpa, Lublin 2008, s. 181-200.

Profantovà Z., Jęzkowy obraz śmierci na Stowacji, „Etnolingwistyka” 10/11 (1997/1998), S. 111-120.

Zgółka T., Retoryka tabuizacji, „Język a Kultura”. Tabu w języku i kulturze, t. 21, red. A. Dąbrowska, Wrocław 2009, s. 23-29. 